\title{
The Globalization of World Politics - The United Nations: Legitimacy or Figure Head?
}

\author{
ANGEL YIADOM BOACHIE*
}

Shanghai University, China

\author{
*Corresponding Author: ANGEL YIADOM BOACHIE, Shanghai University, China
}

\begin{abstract}
The United Nations, a well-known international organization in the contemporary global system, nevertheless, how much do we know about the organization, is it by name or by function? How did it originate, what is its purpose, how is it impacting the global order and has it truly been able to carry its objectives as stipulated at its birth and what can we project that the organization will contribute to maintaining the current international order? A major question we can also ask ourselves is, does the United Nations truly wield any substantive prerogative to facilitate the international order or is its said power in the international system waning? Also, to what extent cam we quantify the legitimacy of the United Nations in global politics. In this paper, we will take a look at the background of the United Nations, how it has or not restricted the international system and as well as some challenges it is facing or has faced.
\end{abstract}

\section{THE HISTORY}

In 1945, after World War II, the participating and non-participating nations were left in ruins; the world sought peace and needed a way forward from the tragedy and destruction of war, and on these reigns, the United Nations was established. However, the name, "United Nations" was purported by the then United States President, Franklin D. Roosevelt during the Second World War in the Atlantic Charter of 1942. After World War II, 51 countries gathered in San Francisco in 1945 to sign a document that would later be known as the Charter of the United Nations, and in doing so, creating a new organization to maintain peace and international order. This charter in question sets out the basic rules and principles governing international order; it can also be referred to as an international treaty, and officially, the United Nations was established on the $24^{\text {th }}$ of October 1945 . Now, according to the Charter, the United Nations at that time had four purposes: maintaining international peace and security, fostering friendly relations among nations, promoting human rights and solving international disputes and serving as a centre for harmonizing the actions of nations, however, throughout the years the organization has added more purposes in reaction to developments in the international system. In addition to this, it is vastly known in international relations that the United Nations was established to succeed where the League of Nations (which was established after the First World War) failed. There were many challenges that the League of Nations faced such as a lack of effective power, no clear distinction of functions, no real means of sanctioning deviant states and so on and on that premise, the United Nations sought to correct. Let us take a look at the structure of the United Nations; how it functions. The United Nations was structured in such a way that its functions would not repeat the mistakes of the League of Nations or be faced with the same problems of the League of Nations. The organization has six main organs: the Security Council; the organ concerned with maintaining international peace and security, the General Assembly; where all member states are represented and partake in decisions, the Secretariat; the organ that deals with the administrative work of the organization led by the Secretary-General, the Economic and Social Council; coordinates the economic and social work of the United Nations and its sub-organizations, the Trusteeship Council; set up to supervise the 11 Trust Territories, the International Court of Justice; the organ concerned with judicial proceedings. In this paper, I particularly want to focus on the United Nation's legitimacy in maintaining international peace and security, assessing its strengths and failures in this area.

\section{Literature REVIEW}

Firstly, delving into the United Nations role in international peace and security

Focusing on the legitimacy of the United Nations, we can discuss on what grounds the organization 
and its organs function. Going in further on the United Nations Security Council, we know that the organ deals with international security issues and whatever it deems a threat to international peace, it is mandated to deal with accordingly. "The Charter grants the Council-wide latitude to "determine the existence of any threat to the peace, breach of the peace, or act of aggression" (Art. 39) and the authority to require-not merely allow or recommend-all kinds of supporting action from the member states when such an international threat, breach, or act has been found (Arts. 40, 41, 42, 36). These determinations and requirements are made by the Council on behalf of the entire organization and all its members (Art. 24). Council decisions are legally binding on all 191-member states, they trump any conflicting domestic law or treaty passed by member governments (Arts. 25, 103), and there is little room for any kind of appeal from its decisions.The Charter may in theory put all the resources of the member states at the disposal of the Council in the enforcement of its decisions (Arts. 43, 45)." (Hurd, 2008). However, how do we question the legitimacy of the Security Council in meeting out its duties? Is it appropriate for it to carry out war strikes in the name of maintaining international peace and security? And can the Council meet out sanctions against nations or states that behave out of line? "Without independent control of military capacity, IOs can only be conduits for the expression of underlying distributions of state power. For this reason, Michael Glennon, upon finding that the Security Council is made up of states that disagree with one another concludes that American unipolarity ultimately makes the Council immaterial. Where IOs do exist, realists suggest that they so closely reflect the distribution of material resources among the states they are comprised of that they add little that is significant to the out-comes of interstate conflicts. Strong states generally win out in the construction of international institutions, and so the interests of these states should be privileged in the IOs. Lloyd Gruber, for example, argues that medium-sized states can be pressured into participating in multilateral schemes when strong states show their willingness to "go it alone." (Hurd, 2008). The United Nations has a convention of non-interventionism, which makes it difficult for it to carry out some of its functions. Nevertheless, in some dire cases it can be seen that the United Nations intervenes, especially in cases of human rights, peacekeeping, crimes against humanity and so on, however, these remain limited. "At the founding of the UN, sovereignty was regarded as central to the system of states. States were equal members of international society and were equal concerning international law. Sovereignty also implied that states recognized no higher authority than themselves and that there was no superior jurisdiction. The governments of states had exclusive jurisdiction within their frontiers; a principle which was enshrined in Article 2(7) of the United Nations Charter. Intervention in the traditional sense was in opposition to the principles of international society, and it could only be tolerated as an exception to the rule." (Taylor \& Curtis, 2008).

\section{Assessing The Un Mandate}

Over the years, we can ascertain that the United Nations has made some tremendous achievements in maintaining world peace, that is to say, so far, it has made continued efforts to prevent another World War, even though there have been minor or proxy wars. Discussing these achievements, the United Nations has maintained world peace by dispatching troops to war or conflict zones around the world to bring down violence and maintain peace; for example, in the case of the Rwandan genocide, the United Nations had to step in and send troops to establish the peace in the area. We can also look at the United Nations achievements in promoting human rights and a prominent landmark of this feat is the United Nations Declaration of Human Rights, which has helped immensely with the promotion of fundamental human rights all over the globe. In addition, the United Nations also helped with decolonization; at the time it was formed, most of the countries in the periphery were still colonized and so it helped in some way for them to achieve independence and allowing for them to attain membership. The United Nations is the main body that purported international law of how states should relate with each other at the diplomatic level, also laws that indicate sea space and air space of a country where a violation of these boundaries results in consequences. Finally, the United Nations has served as a forum for discussing international issues and the fight against the global drug trade. In the same vein, the United Nations has faced and faces many challenges despite its outstanding achievements, in my opinion. We can talk about its financial problems with some member-states refusing or failing to pay their dues; this is because a large portion of the United Nations membership is from the Third World and so there is a difficulty in raising funds for payment, we also see the refusal of certain great power countries like the United States deliberating delaying in paying dues. Another problem is that of sovereign inequality amongst member states in the sense that, some countries are deemed more important than others especially the richer nations. The United Nations has 
also found it difficult to organize a permanent or standing army making it difficult for it to enforce certain resolutions it passes as well as being unable to punish member- nations that donot adhere to these resolutions. Also, there is a misuse of veto power by the permanent members of the Security Council; these members sometimes try to undermine the efforts of the organization in solving some international conflicts or problems by using their veto power. In addition, we see that the organization faces some issues of ideological differences such as capitalism versus communism and so on, and this is in turn creates disharmony within the organization with a difficulty in securing agreements of international matters. The United Nations has not fully been able to resolve the issue of the refugee crisis in the world with a steady increase in the movement of refugees from the periphery to the core countries, especially in Europe. Assessing the achievements of the United Nations against the challenges it faces, we can see that the United Nations has a long way to go in asserting itself as a power that can maintain and ensure world peace and security.

\section{THE UN \& THE IRAQ WAR}

I want us to take a look at and discuss to an extent interventionism and non-interventionism on the part of the United Nations and its consequences in the international system and using the 2003 intervention in Iraq as a case study. "In March 2003, a US-led coalition launched a highly controversial war in Iraq, which removed Saddam Hussein from power. The justification for war stressed Iraq's possession of weapons of mass destruction, in defiance of earlier UN resolutions. Unlike in Kosovo, the growing violation of human rights was not given as a main justification for the invasion until later. Yet the failure to find weapons of mass destruction in Iraq as well as the ongoing civil war, have fueled the claims of critics that the war was unjustified. There was no agreement over whether the UN Security authorized military action in Iraq. American and British Diplomats pointed to the UN Security Council Resolution 687 of 1991, which required the destruction of Iraqi weapons of mass destruction under UN supervision, and UN Security Council Resolution 1441 of 2002 which threatened 'serious consequences' if this were not done. Yet efforts to reach a Security Council resolution in the winter of 2003 that would clearly authorize the use of force against Iraq were unsuccessful. France and Russia threatened to veto a second Security Council resolution authorizing force." (Baylis, Smith \& Owens, 2008). In my opinion the United Nations, specifically the Security Council, which is tasked with maintaining international peace and security, failed again in this regard. During the Cold War, I found the United Nations rather neutral in playing a key role in the demise of the war, I say this because it was a war between two of the permanent members of the Security Council making it very hard for any kind of resolution to be reached. In addition, the United Nations could not intervene in the politics of the cold war, which in the long run led to the demise of the Soviet Union, however, the back-and-forth and 'blame-game' politics between Russia and the United States has not ceased thereby inhibiting any kind of progress the Security Council can make in maintaining international peace and security. These same characteristics repeated themselves in the case of the Iraq invasion by the United States, although the Security Council did not sanction the invasion, the United States went ahead anyway as it is the most powerful nation in our international system; so truly, does the United Nations hold any kind of power in the International System? Or can hegemons always do as they please regardless of International law? I believe that the United Nations as a whole needs vast reforms and inclusive resolution on the part of the General Assembly on all levels, that is, political, social, economic and military wise for it to function effectively in the international system, thereby ensuring world peace as it was set up to do. In the event that the United Nations legitimizes its authority in the international system and not just be a ceremonial figure of international peace, we will see more states behave accordingly with international law and the world, I believe, will see true peace and stability.

\section{CONCLUSION}

The United Nations is an organization that was founded to ensure international peace and security as well as ensure the fundamental human rights of all human beings in the world amongst others. Indeed, the organization has been able to achieve over the decades some of the objectives for which it is founded such as maintaining international peace and security as well as preventing any major world war, ensuring fundamental human rights, aiding in resolving the world's refugee crisis, humanitarian activities, improving worldwide socio-economic welfare, resolving political issues between states as well as helping with decolonization and so on. Nevertheless, we ascertained that in as much as it has achieved so much over the years it has also faced many challenges that have hindered its true progress. 
The Security Council, which is one of its most important organs, has failed in some cases to deploy the right military action in resolving some international security issues. The capacity of the United Nations work, effort and power need to enhanced to see it truly affect real change in the international system. That notwithstanding, efforts made thus far by the organization are tangible and continued efforts are being realized for the wholesome balance of international order.

\section{BIBLIOGRAPHY}

[1] Baylis, J., Smith, S., \& Owens, P. (2008). The Globalization of World Politics: An introduction to international relations, The United Nations(pp. 645-680). Oxford: Oxford University Press.

[2] Hurd, I. (2008). After Anarchy: Legitimacy and Power in the United Nations Security Council. Princeton and Oxford: Princeton University Press.

[3] Jasper, W. M. (1992). Global Tyranny Step by Step: The United Nations and the Emerging New World Order.United States of America: Western Islands.

[4] The United Nations website. (2019, October 4). Retrieved November 12, 2019, from https://www.un. org/en/

Citation: ANGEL YIADOM BOACHIE. "The Globalization of World Politics - The United Nations: Legitimacy or Figure Head?" International Journal of Political Science (IJPS), vol 7, no.2, 2021, pp. 5-8. doi: https://doi.org/10.20431/2454-9452.0702002.

Copyright: () 2021 Authors. This is an open-access article distributed under the terms of the Creative Commons Attribution License, which permits unrestricted use, distribution, and reproduction in any medium, provided the original author and source are credited. 